Abstracta Iranica Iranica

Revue bibliographique pour le domaine irano-aryen

Volume 22 | 2001

Comptes rendus des publications de 1999

\title{
Hedāyat va Sepehrī. Tehrān, Hāšemī, 1378/1999, 190 p. [Hedāyat et Sepehrī]
}

\section{Christophe Balaÿ}

\section{(2) OpenEdition}

1 Journals

\section{Édition électronique}

URL : http://journals.openedition.org/abstractairanica/37147

DOI : 10.4000/abstractairanica.37147

ISSN : 1961-960X

Éditeur :

CNRS (UMR 7528 Mondes iraniens et indiens), Éditions de l'IFRI

\section{Édition imprimée}

Date de publication : 15 mai 2001

ISSN : 0240-8910

\section{Référence électronique}

Christophe Balaÿ, « Hedāyat va Sepehrī. Tehrān, Hāšemī, 1378/1999, 190 p. [Hedāyat et Sepehrī] », Abstracta Iranica [En ligne], Volume 22 | 2001, document 554, mis en ligne le 17 février 2010, consulté le 13 octobre 2020. URL : http://journals.openedition.org/abstractairanica/37147 ; DOI : https:// doi.org/10.4000/abstractairanica.37147

Ce document a été généré automatiquement le 13 octobre 2020.

Tous droits réservés 


\title{
Hedāyat va Sepehrī. Tehrān, Hāšemī, 1378/1999, 190 p. [Hedāyat et Sepehrī]
}

\author{
Christophe Balaÿ
}

B. Meqdādī, professeur à l'Université de Téhéran, plaide pour une nouvelle critique littéraire. En revisitant la lecture de deux œuvres majeures du $20^{\mathrm{e}} \mathrm{s}$. («La chouette aveugle » de Ș. Hedāyat et «Les Huit Livres » de Sohrāb Sepehrī) il montre qu'un autre regard peut être porté sur le patrimoine littéraire persan moderne, démarqué, à la fin, d'une lecture traditionnelle et littérale (la tradition philologique) et de la théorie de l'imitation et de l'influence. Des quatre essais, trois sont consacrés à l'œuvre de Hedāyat: le premier, une double lecture de Būf-e kūr et des Raisins de la colère, de J. Steinbeck, une lecture jungienne de Büf-e kūr et de "Trois gouttes de sang», ainsi qu'une remise en perspective de $B \bar{u} f-e ~ k u \bar{r}$ dans la littérature mondiale. Le quatrième essai est dédié à la poésie de Sepehrī, débarrassée de son mythe ésotérique et de son exotisme oriental. En quatre essais, Meqdādī offre sa lecture comparatiste de la prose et de la poésie persanes contemporaines. On regrettera peut-être le recours aux critiques occidentales qui contredisent un peu cette volonté 登 très justifiée 医 de bâtir un discours critique persan authentique. L'absence de repères logiques à l'intérieur des quatre chapitres affecte aussi la lisibilité de ce discours.

\section{INDEX}

Thèmes : 11.1.2. Littérature persane moderne 
AUTEURS

CHRISTOPHE BALAŸ

IFRI - Téhéran 